УДК 336.02

Власюк H. I., natalilty1706@gmail.com,ORCID:0000-0002-9463-5626,

Researcher ID: F-1812-2019,

к.е.н.,доч., дочент кафедри фінансів, кредиту та страхування, Львівський торговельно-економічний університет, м. Львів

\title{
ВПЛИВ МАКРОЕКОНОМІЧНИХ ЧИННИКІВ НА ФОРМУВАННЯ ТА ВИКОРИСТАННЯ ПРИБУТКУ ПІДПРИЕМСТВ
}

\begin{abstract}
Анотація. У системі економічних показників фінансові результати, у яких відображені різні сторони виробничої, збутової, постачальницької і фінансової діяльності підприємства, посідають чільне місие. Сучасна практика засвідчує гостру необхідність досліджень формування та використання прибутку, підтвердженням чого є хронічна нестача коштів практично в усіх секторах фінансової системи України та незадовільний фінансовий стан значної частини суб' єктів господарювання. У зв'язку з цим гострою потребою стало всебічне $i$ детальне вивчення прибутку, який займає центральне місце в загальній системі вартісних інструментів $і$ важелів управління економікою. Це виражається в тому, щзо фінанси, кредит, иіни, собівартість та інші важелі прямо чи опосередковано пов'язані з прибутком. У статті обтрунтовано теоретико-методичні підходи стосовно ролі держави та системи макроекономічних чинників впливу на фінансові результати діяльності суб'єктів господарювання. Проведено аналіз фінансових результатів (прибутку та рентабельності) підприємств Украйни за 2014-2018 рр. Висвітлено завдання комплексу першочергових інституційних перетворень, які сприятимуть у майбутньому зростанню прибутковості підприємств та посиленню активності держави у формуванні економічних і правових умов діяльності суб'єктів господарювання України. Проведені дослідження переконують у тому, щьо позитивний вплив макроекономічних (зовнішніх) факторів справляє вкрай важливий вплив на формування фінансових результатів діяльності підприємств. Зроблено висновок, щзо завдання держави - максимізувати резерви підвищення прибутковості суб' 'ктів господарювання у царині державної фінансової політики.
\end{abstract}

Ключові слова: макроекономічні чинники, прибуток, збиток, рентабельність, формування та використання прибутку, управління прибутком.

Vlasyuk N. I., natalilty1706@ gmail.com, ORCID: 0000-0002-9463-5626,

Researcher ID: F-1812-2019,

Ph.D., Associate Professor, Associate Professor of the Department of Finance, Credit and Insurance, Lviv University of Trade and Economics, Lviv

\section{THE INFLUENCE OF MACROECONOMIC FACTORS ON THE FOR- MATION AND USE OF ENTERPRISES PROFITS}

\begin{abstract}
In the system of economic indicators, financial results, which reflect various aspects of production, sales, supply and financial activities of the enterprise, occupy a prominent place. Modern practice shows the urgent need for research on the formation and use of profits, confirmation of what is the chronic lack of funds in almost all sectors of the financial system of Ukraine and the unsatisfactory financial condition of many businesses. Therefore, a comprehensive and detailed study of profits, which is central to the overall system of financial instruments and levers of economic management, has become an urgent need. This means that finance, credit, prices, costs and other levers are directly or indirectly related to profits. The article substantiates the theoretical and methodological approaches to the role of the state and the system of macroeconomic factors influencing the financial performance of economic entities. The analysis of financial results (profit and efficiency) of enterprises of Ukraine for 2014-2018 is carried out. The tasks of the priority institutional transformations which will promote in the future growth of profitability of the enterprises and strengthening of activity of the state in providing of economic and legal conditions for Ukrainian business entities activities are highlighted. The research shows that the positive impact of macroeconomic (external) factors has an extremely important impact on the formation of financial results of enterprises. It is concluded that the task of the state is to maximize the reserves of increasing the profitability of economic entities in the field of public financial policy.
\end{abstract}

Key words: macroeconomic factors, profit, loss, profitability, formation and use of profit, profit management.

JEL Classification: E62

DOI: https://doi.org/10.36477/2522-1205-2021-62-09 


\section{Herald of Lviv University of Trade and Economics. Economic Sciences. № 62, 2021}

Постановка проблеми. Зменшення здатності національної економіки продукувати додану вартість, частину якої складають прибутки, є однією 3 основних причин кризових явищ в економіці України.

Подальший розвиток економіки та фінансової системи фактично неможливий без практичної перевірки теоретичних напрацювань (категорійного апарату, моделей, схем, конструкцій), оцінки загального стану й окремих тенденцій, аналізу структури та динаміки доходів і видатків як у цілому по системі, так і в розрізі її окремих складових, зокрема в частині формування та використання прибутку суб'єктів господарювання, що в умовах ринку $\epsilon$ найбільш бажаним джерелом приросту фінансових ресурсів.

Винятково важлива роль прибутку в формуванні та використанні певної частини суспільного продукту та фінансових ресурсів суб'єктів господарювання ні в кого не викликає заперечення. В той же час надвисокі частки тіньової економіки та збиткових підприємств, наднизькі рівні рентабельності та незначні фінансові результати прибуткових підприємств не можуть не викликати сумнівів і заперечень щодо обгрунтованості економічної політики держави та суб'єктів господарювання щодо формування і використання такої важливої складової доданої вартості, якою є прибуток. Це, у свою чергу, викликає гостру потребу в пошуку нових поглядів та підходів до формування та використання прибутку, що особливо важливо в умовах зростання відкритості національної економіки та посилення глобалізаційних процесів.

Аналіз останніх досліджень і публікацій. Проблемам ролі держави у формуванні та використанні прибутку підприємств присвячено значну кількість праць як зарубіжних, так і українських дослідників, зокрема: Г. М. Азаренкової, М. М. Алексеєва, I. О. Бланка, М. М. Бердара, А. М. Бортника, Е. Ф. Брігхема, Т. М. Журавля, М. Я. Коробова, О. О. Орлова, А. М. Поддєрьогіна, О. Тулай, В. І. Кузь, Р. М. Михайленка, О. В. Хмелевського, Л. П. Дядечка, Т. О. Кірсанової, Я. О. Панасюк та ін. Однак деякі аспекти щодо впливу макроекономічних чинників на формування та використання прибутку комерційних підприємств залишаються дискусійними та потребують подальшої розробки.

Постановка завдання. Метою статті є дослідження впливу системи макроекономічних чинників на формування та використання прибутку комерційних підприємств.

Виклад основного матеріалу дослідження. Сучасна практика засвідчує гостру необхідність подальших досліджень формування та використання прибутку, підтвердженням чого $\epsilon$ хронічна нестача коштів практично в усіх секторах фінансової системи України та незадовільний фінансовий стан значної частини суб'єктів господарювання, що $\epsilon$ також свідченням неналежної організації управління фінансами на мікро- та макрорівнях економіки. У даному випадку управління прибутком на різних рівнях економіки повинно не носити неузгоджений, суперечливий характер, а органічно взаємодоповнюватись.

Відсутність прибутків або їх обмеженість у просторі та часі, а також обмежені можливості збільшення маси прибутку привели до втрати мотивації до ведення бізнесу, інвестицій та розширення виробництва. Зазначені явища вказують на кризу інституційної моделі, на якій базовано отримання прибутку.

У період до 2014 р. в Україні сформувалися такі інституційні умови, при яких домінуючим напрямом максимізації прибутків у бізнесі, окрім використання природних переваг, стало штучне заниження вартості робочої сили. У той же час основною конкурентною перевагою, необхідною для одержання прибутку, стала економічна влада, до якої належать: монопольна ринкова влада; вертикальна інтеграція; внутрішньокорпоративна влада, яка диктує режим і умови оплати праці; доступ і використання в приватних цілях державної, зокрема правоохоронної та судової влади; використання приватного насильства, як легалізованого (структури безпеки), так і кримінального порядку тощо.

Проте такий механізм одержання економічного прибутку шляхом захоплення i розподілу ренти влади має свої межі, які наразі можна вважати вичерпаними. Для цього $є$ комплекс причин:

- по-перше, штучне заниження цін на витрати виробництва можливе лише до деякого критичного рівня, наслідком переходу якого $є$ порушення умов відтворення ресурсів, необхідних для ведення виробничої діяльності;

- по-друге, інтереси максимізації прибутків i, відповідно, мінімізації витрат виробництва входять у суперечність з інтересами держави, іiї соціальною та інфраструктурною політикою;

- по-трете, до негативних наслідків інституційної моделі одержання прибутку, що наразі склалася в Україні, треба віднести відторгнення інновацій, поглиблення диспропорцій у розвитку видів економічної діяльності, низьку якість економічного зростання;

- по-четверте, високі темпи науковотехнічного прогресу в світовій економіці, завдяки чому прискорене зниження фізичних витрат виробництва випереджає можливості вітчизняних підприємств із отримання занижених цін на ресурси (природні та трудові) [1].

Крім того, впровадження нових технологій призводить до створення продукції з такими якісними характеристиками, які вітчизняна економіка виробляти вже у принципі не в змозі. У результаті спостерігається поступове зниження якісної “ніші” української продукції на світових ринках і реальна загроза іiі витіснення 3 передових світових ринків загалом.

Вичерпання ресурсних резервів створення прибутку (резервів для заниження витрат виробництва) призводить до вичерпання джерел економічного зростання.

Реальне досягнення стану прибутковості суб'єктів господарювання України залежить від активності держави у формуванні економічних i 
правових умов діяльності господарюючих суб'єктів України. Формування та використання прибутку суб'єктів господарювання у даному випадку не $\epsilon$ винятком, оскільки повинно мати належне нормативно-правове забезпечення, яке визначає загальні (бажано сучасні, тобто прогресивні та єдині для всіх учасників) правила, умови, норми та нормативи тощо фінансово-господарської діяльності. Крім того, особливо важливою в сучасних умовах $є$ належна організація обліку та звітності. Система звітності за доходами та витратами на сучасних підприємствах з метою забезпечення порівняльності їх фінансових показників повинна мати у своїй основі єдине нормативно-правове забезпечення.

В Україні сьогодні залишається чимало проблем і недоліків, що перешкоджають розвитку не лише підприємницької діяльності, але й економіки загалом. Такі недоліки, що тепер спостерігаються як у частині правового забезпечення, так і специфічних норм господарювання, потрібно послідовно виправляти для створення нових стимулів розвитку підприємництва. Вирішенню цього завдання певною мірою може сприяти імплементація в українське господарське законодавство європейських норм. Проте в цілому проблема $є$ більш складною і комплексною, зачіпаючи, у тому числі, базові інститути, які визначають мотивацію економічних суб'єктів.

Центральною проблемою економічної політики має стати відтворення джерел одержання прибутку i формування ефективних інституційних моделей його максимізації, без чого неможливо забезпечити стійке економічне зростання внаслідок відсутності необхідної мотивації та інвестиційних ресурсів.

Для цього необхідно перейти від теперішніх інституційних форм ведення бізнесу і максимізації прибутку, базованих на надлишку економічної влади та штучному заниженні витрат ведення бізнесу.

Становлення та подальший розвиток ринкових відносин в Україні значною мірою залежить від активності держави у формуванні економічних i правових умов діяльності суб'єктів господарювання
України. Формування та особливо використання прибутку, судячи з попередньої практики, не повинно бути винятком, оскільки повинно мати належне нормативно-правове забезпечення, яке визначає загальні (отже, сучасні та єдині для всіх учасників) правила та норми поведінки у фінансово-господарській діяльності.

Визначаючи пропорції розподілу прибутку, держава опосередковано впливає на інші складові управління. Встановлюючи у тих чи інших випадках норми витрат (сировини, матеріалів, оплати праці, відрахування у соціальні фонди тощо), норми рентабельності, відрахування до резервного капіталу, дивідендів тощо, держава формує правила економічної поведінки суб'єктів господарювання. Подібні правила (фактично умови) з метою формування ринкового середовища відкритого типу не повинні носити вибіркового (отже, фрагментарного) характеру, оскільки не будуть взаємоприйнятними для усіх інших суб'єктів фінансової системи. Пільги та інші преференції, що дають економічні переваги в одних напрямах діяльності, зазвичай нівелюються втратами в інших.

Стан і рух фінансових ресурсів між суб'єктами фінансової системи у найбільш узагальненому вигляді відображають показники ВВП за категоріями доходу та використання. ВВП вважається основним макроекономічним показником результатів економічної діяльності, використовується для порівняльного аналізу на міжнародному рівні, оцінки ефективності економіки тощо. Крім того, це один із основних показників системи національних рахунків. Він характеризує кінцевий результат виробничої діяльності економічних одиниць на економічній території країни. Структура ВВП за категоріями доходу в розрізі заробітної плати, прибутку та податків свідчить про первинний розподіл ресурсів між економічними суб'єктами (населенням, суб'єктами господарювання та державою), про потенційні можливості подальшого споживання та нагромадження.

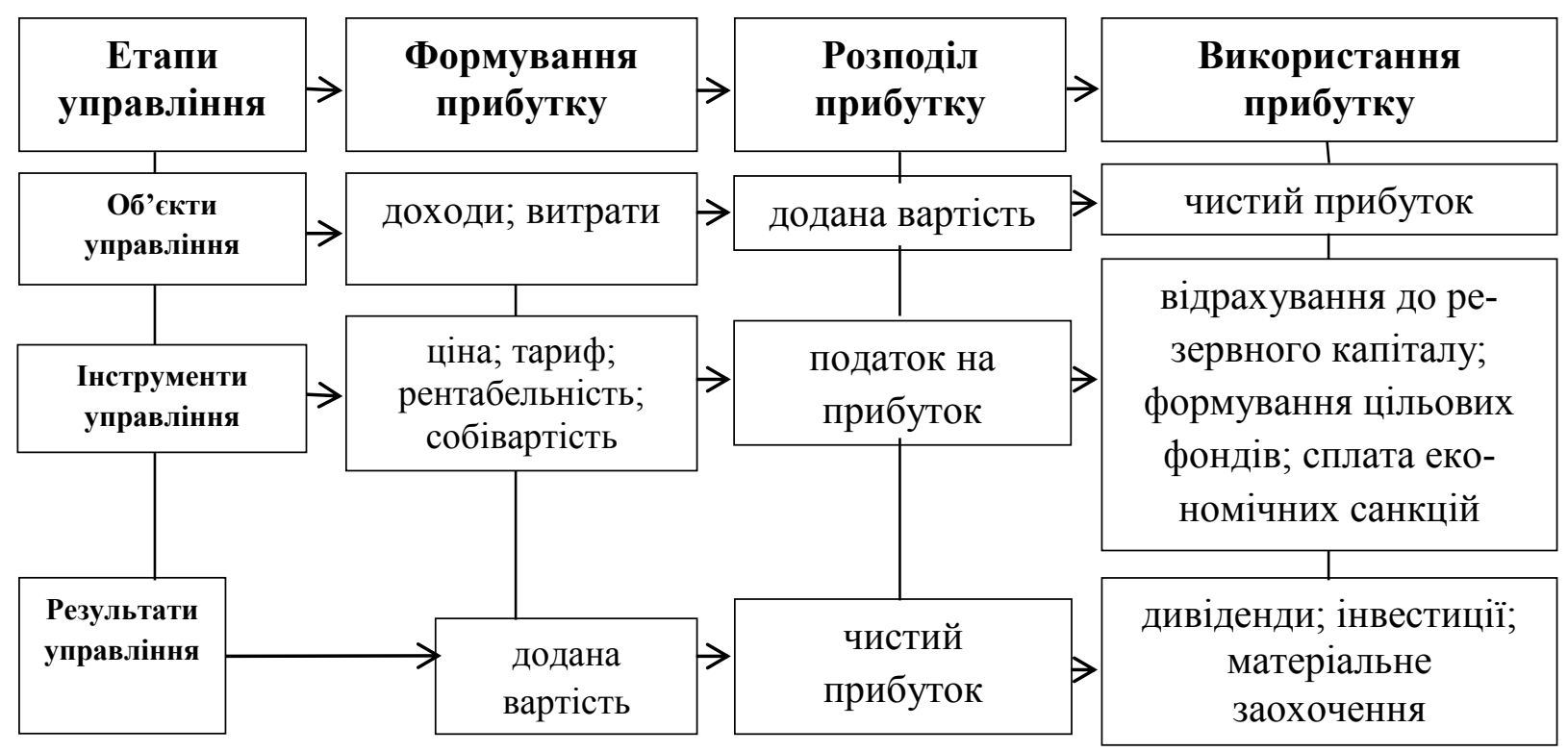

Рис. 1. Складові процесу управління прибутком суб'сктів господарювання України [2] 
Окремі складові процесу управління прибутком, що заслуговують особливої уваги при розробці стратегії удосконалення його формування та використання, відображено на рис. 1 .

Прослідкуємо динаміку формування фінансового результату до оподаткування, чистого прибутку та рентабельності на підприємствах України за 2014-2018 рр. (табл. 1, 2 та 3).

Як бачимо за даними табл. 1, якщо у 2014 році найбільшу частку прибуткових підприємств складали малі суб'єкти господарювання, то у 2018 році - середні підприємства, тобто акценти змістилися. Протягом аналізованого періоду частка великих збиткових підприємств скоротилася з 48,2 \% до $23,1 \%$, що $є$ позитивним. Частка середніх підприємств, які перебували у зоні збитковості протягом 2014-2018 рр., зменшилася на 15,6 \%, що теж $\epsilon$ позитивним. Збитковість малих підприємств знизилася на 7,6\%.

Як показують проведені у табл. 2 розрахунки, збиток за видами економічної діяльності спостерігався протягом 2014-2015 рр., починаючи з 2016 року, загальний показник увійшов у зону прибутковості, що є позитивним. У 2014 році всі галузі, крім сільського господарства та освіти, перебували у зоні збитковості. У 2018 році у зоні збитковості залишилися лише транспорт, операції з нерухомим майном, діяльність у сфері адміністративного та допоміжного обслуговування та у сфері мистецтва, спорту, розваг та відпочинку. Всі інші галузі стали прибутковими, тобто динаміка $є$ позитивною.

Порівняно з 2017 роком у звітному періоді покращилася ситуація у будівництві та наданні інших послуг: вони вийшли із зони збитковості.

Як бачимо, протягом аналізованого періоду із зони збитковості у зону прибутковості перейшли підприємства оптової і роздрібної торгівлі, організація харчування, інформація та телекомунікації, фінансова та страхова діяльність, наукова та технічна діяльність, охорона здоров'я та надання інших видів послуг.

Продовжують залишатися у зоні збитковості транспорт, операції з нерухомим майном, діяльність у сфері адміністративного та допоміжного обслуговування, мистецтво, спорт, розваги та відпочинок.

Тобто наразі в Україні потрібно усунути приватну економічну владу як джерело одержання економічної ренти і створювати умови для переходу до бізнес-стратегій, у яких одержання і максимізація прибутку грунтується на таких конкурентних перевагах, як ефективність організацій бізнесу, інноваційна стратегія зростання, підвищення якості та швидкості бізнес-процесів.

Здійснення такої політики має відбуватися за рахунок комплексу першочергових інституційних перетворень:

- обмеження монополізму і вживання заходів щодо захисту економічної конкуренції. Це положення має реалізуватися шляхом введення відповідальності за антиконкурентні дії з боку органів влади, органів місцевого самоврядування, органів адміністративно-господарського управління і контролю, що має бути затверджено внесенням відповідних змін до Закону України "Про захист економічної конкуренції”;

- приведення номінального акціонерного капіталу у відповідність із реальним капіталом. Необхідно провести реальну корпоратизацію цілісних господарських структур, що склалися до цього часу. Ідеться про перетворення на відкриті акціонерні товариства нинішніх закритих бізнес-структур, які контролюють стратегічні господарські комплекси, унаслідок чого їх нинішні власники мають стати звичайними утримувачами акцій разом 3 іншими можливими співвласниками;

- обмеження режиму власності фізичних осіб у великих корпоративних структурах; потрібна інституалізація власності, зокрема шляхом розширення перехресного володіння акціями між акціонерними підприємствами, які утворюють мережеві структури ведення бізнесу;

- обмеження вертикальної інтеграції бізнесу, скорочення адміністративних бар'єрів і вживання заходів щодо зменшення розміру трансакційних витрат і підвищення швидкості бізнес-процесів;

- введення дієвих законодавчих обмежень та заборон на використання офшорних структур 3 метою трансфертного ціноутворення [4].

Табличя 1

Частка підприємств України, які одержали прибуток чи збиток (фінансовий результат до оподаткування) за 2014-2018 pp. (\%)

\begin{tabular}{|c|c|c|c|c|c|c|c|c|c|c|}
\hline \multirow[b]{2}{*}{$\begin{array}{c}\text { Види } \\
\text { підприємств }\end{array}$} & \multicolumn{2}{|c|}{$2014 \mathrm{p}}$. & \multicolumn{2}{|c|}{2015 p. } & \multicolumn{2}{|c|}{$2016 \mathrm{p}}$. & \multicolumn{2}{|c|}{$2017 \mathrm{p}$} & \multicolumn{2}{|c|}{$2018 \mathrm{p}}$. \\
\hline & 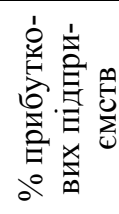 & 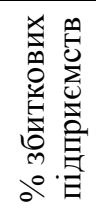 & 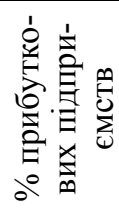 & 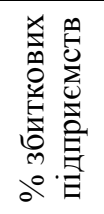 & 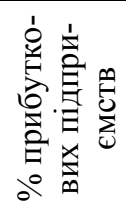 & 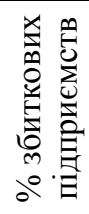 & 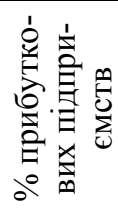 & 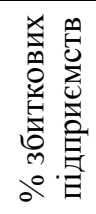 & 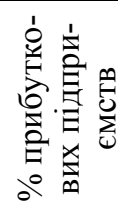 & 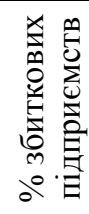 \\
\hline $\begin{array}{l}\text { Великі підпри- } \\
\text { ємства }\end{array}$ & 51,8 & 48,2 & 55,7 & 44,3 & 65,8 & 34,2 & 73,3 & 26,7 & 76,9 & 23,1 \\
\hline $\begin{array}{l}\text { Середні під- } \\
\text { приємства }\end{array}$ & 62,6 & 37,4 & 71,1 & 28,9 & 76,1 & 23,9 & 76,6 & 23,4 & 78,2 & 21,8 \\
\hline $\begin{array}{l}\text { Малі підпри- } \\
\text { ємства }\end{array}$ & 66,5 & 33,5 & 73,9 & 26,1 & 73,3 & 26,7 & 72,7 & 27,3 & 74,1 & 25,9 \\
\hline
\end{tabular}

Джерело: складено автором за [3] 
Вісник Львівського торговельно-економічного університету. Економічні науки. № 62, 2021

Динаміка чистого прибутку (збитку) підприємств України за видами економічної

Таблиия 2 діяльності за 2014-2018 рр.

\begin{tabular}{|c|c|c|c|c|c|c|c|}
\hline \multirow{2}{*}{$\begin{array}{c}\text { Види економічної } \\
\text { діяльності }\end{array}$} & \multicolumn{5}{|c|}{ Чистий прибуток (збиток), млн грн } & \multicolumn{2}{|c|}{$\begin{array}{c}\text { Відхилення (+, -) } \\
2018 \text { від }\end{array}$} \\
\hline & 2014 p. & $2015 \mathrm{p}$. & $2016 \mathrm{p}$. & 2017 p. & 2018 p. & 2014 & 2017 \\
\hline $\begin{array}{l}\text { Сільське, лісове та } \\
\text { рибне господарство }\end{array}$ & 21481,3 & 102849,1 & 90613,2 & 68858,5 & 71002,6 & 49521,3 & 2144,1 \\
\hline Промисловість & $-178730,9$ & $-188267,9$ & $-24724,7$ & 56124,0 & 109288,8 & 288019,7 & 128019,7 \\
\hline Будівництво & $-27948,8$ & $-25861,9$ & $-10553,0$ & $-5014,3$ & 4414,1 & 32362,9 & 9428,4 \\
\hline $\begin{array}{l}\text { Оптова та роздрібна } \\
\text { торгівля }\end{array}$ & $-133219,4$ & $-88161,0$ & $-4841,8$ & 25854,2 & 68809,8 & 202029,2 & 42955,6 \\
\hline Транспорт & $-22591,6$ & $-17847,8$ & 7408,7 & 16796,7 & $-24265,4$ & $-1673,8$ & $-41062,1$ \\
\hline $\begin{array}{l}\text { Організація харчу- } \\
\text { вання }\end{array}$ & $-6641,9$ & $-6874,9$ & $-1983,1$ & 1773,5 & 2350,9 & 8992,8 & 577,4 \\
\hline $\begin{array}{l}\text { Інформація та теле- } \\
\text { комунікації }\end{array}$ & $-17137,1$ & $-12590,2$ & 1750,6 & 12029,3 & 14676,1 & 31813,2 & 2646,8 \\
\hline $\begin{array}{l}\text { Фінансова та стра- } \\
\text { хова діяльність }\end{array}$ & $-5550,3$ & $-9573,5$ & $-670,8$ & 16806,6 & 23096,2 & 28646,5 & $-14500,4$ \\
\hline $\begin{array}{l}\text { Операції з нерухо- } \\
\text { мим майном }\end{array}$ & $-105425,7$ & $-64369,0$ & $-43900,2$ & $-17551,2$ & $-1551,6$ & 13874,1 & 15999,6 \\
\hline $\begin{array}{l}\text { Професійна, науко- } \\
\text { ва та технічна дія- } \\
\text { льність }\end{array}$ & $-100347,2$ & $-48656,0$ & 22842,0 & 32356,1 & 20304,4 & 120651,6 & $-12051,7$ \\
\hline $\begin{array}{l}\text { Діяльність у сфері } \\
\text { адміністративного } \\
\text { та допоміжного } \\
\text { обслуговування }\end{array}$ & $-9543,2$ & $-9860,6$ & $-5094,4$ & $-3624,2$ & $-493,1$ & 9050,1 & $-1306,8$ \\
\hline Освіта & 62,5 & 80,7 & 76,8 & 96,1 & 138,3 & 75,8 & 42,2 \\
\hline $\begin{array}{l}\text { Охорона здоров’я } \\
\text { та надання соціаль- } \\
\text { ної допомоги }\end{array}$ & $-1185,3$ & $-1042,3$ & 186,2 & 145,0 & 1022,0 & 2207,3 & 877,0 \\
\hline $\begin{array}{l}\text { Мистецтво, спорт, } \\
\text { розваги та відпочи- } \\
\text { нок }\end{array}$ & $-3244,0$ & $-3566,3$ & $-1599,5$ & $-2300,4$ & $-597,1$ & 2646,9 & 1703,3 \\
\hline $\begin{array}{l}\text { Надання інших } \\
\text { видів послуг }\end{array}$ & $-45,3$ & 225,6 & 195,0 & $-23,7$ & 109,5 & 154,8 & 133,2 \\
\hline Усього & $-590066,9$ & $-373516,0$ & 29705,0 & 168752,8 & 288305,5 & 878372,4 & 119552,7 \\
\hline
\end{tabular}

Джерело: складено автором за [3] 
Herald of Lviv University of Trade and Economics. Economic Sciences. № 62, 2021

Рівень рентабельності (збитковості) операційної діяльності підприємств України за 2014-2018 рр.

Таблиия 3

\begin{tabular}{|l|c|c|c|c|c|c|c|}
\hline \multirow{2}{*}{$\begin{array}{l}\text { Види економічної } \\
\text { діяльності }\end{array}$} & \multicolumn{5}{|c|}{ Рівень рентабельності (збитковості), \% } & \multicolumn{2}{c|}{$\begin{array}{c}\text { Відхилення (+,-) } 2018 \\
\text { від }\end{array}$} \\
\cline { 2 - 8 } & 2014 p. & 2015 p. & 2016 p. & 2017 p. & 2018 p. & 2014 & 2017 \\
\hline $\begin{array}{l}\text { Сільське, лісове та } \\
\text { рибне господарство }\end{array}$ & 20,6 & 41,7 & 32,4 & 22,4 & 13,7 & $-6,9$ & $-8,7$ \\
\hline Промисловість & 1,6 & 0,9 & 4,2 & 6,8 & 3,3 & 1,7 & $-3,5$ \\
\hline Будівництво & 5,8 & $-7,6$ & $-0,4$ & 1,6 & 1,3 & $-4,5$ & $-0,3$ \\
\hline $\begin{array}{l}\text { Оптова та роздрібна } \\
\text { торгівля }\end{array}$ & $-12,8$ & $-0,9$ & 15,8 & 18,8 & 11,4 & 24,2 & $-7,4$ \\
\hline Транспорт & $-1,7$ & 1,1 & 5,1 & $-1,0$ & $-4,3$ & $-2,6$ & $-3,3$ \\
\hline $\begin{array}{l}\text { Організація харчу- } \\
\text { вання }\end{array}$ & $-25,8$ & $-17,3$ & $-0,8$ & 7,8 & 5,8 & 31,6 & $-2,0$ \\
\hline $\begin{array}{l}\text { Інформація та теле- } \\
\text { комунікації }\end{array}$ & $-1,6$ & 0,5 & 8,5 & 13,8 & 8,6 & 10,2 & $-5,2$ \\
\hline $\begin{array}{l}\text { Фінансова та страхо- } \\
\text { ва діяльність }\end{array}$ & $-15,2$ & $-8,9$ & $-4,8$ & 2,8 & 13,9 & 29,1 & 11,1 \\
\hline $\begin{array}{l}\text { Операції з нерухо- } \\
\text { мим майном }\end{array}$ & $-46,9$ & $-33,4$ & $-8,1$ & 6,2 & $-0,8$ & 46,1 & $-7,0$ \\
\hline $\begin{array}{l}\text { Професійна, наукова } \\
\text { та технічна діяль- } \\
\text { ність }\end{array}$ & $-29,1$ & $-1,1$ & 17,6 & 19,4 & 5,9 & 35,0 & $-13,5$ \\
\hline $\begin{array}{l}\text { Діяльність у сфері } \\
\text { адміністративного та } \\
\text { допоміжного обслу- } \\
\text { говування }\end{array}$ & $-13,6$ & $-11,9$ & $-3,9$ & 2,6 & $-0,5$ & 13,1 & $-3,1$ \\
\hline Освіта & $-11,8$ & $-25,3$ & $-16,5$ & $-15,5$ & $-3,7$ & 8,1 & 11,8 \\
\hline $\begin{array}{l}\text { Охорона здоров'я та } \\
\text { надання соціальної } \\
\text { допомоги }\end{array}$ & $-3,7$ & $-0,6$ & 4,5 & 3,3 & 2,6 & 6,3 & $-0,7$ \\
\hline $\begin{array}{l}\text { Мистецтво, спорт, } \\
\text { розваги та відпочи- } \\
\text { нок }\end{array}$ & $-1,0$ & 7,3 & 5,1 & $-0,4$ & 2,0 & 3,0 & 2,4 \\
\hline $\begin{array}{l}\text { Надання інших видів } \\
\text { послуг }\end{array}$ & 5,7 & 5,6 & 3,7 & 3,3 & $-2,2$ & $-0,4$ \\
\hline
\end{tabular}

Джерело: складено автором за [3]

Висновки і перспективи подальших досліджень у даному напрямі. Проведені дослідження переконують у тому, що позитивний вплив макроекономічних (зовнішніх) факторів справляє вкрай важливий вплив на формування фінансових результатів діяльності підприємств. Тому завдання держави - максимізувати резерви підвищення прибутковості суб'єктів господарювання у царині державної фінансової політики.

\section{ЛIТЕРАТУРА}

1. Басюркіна Н. Й. Аналіз і оцінка зовнішніх і внутрішніх чинників формування прибутку у виноробній галузі / Н. Й. Басюркіна // Економіка харчової промисловості [Електронний ресурс]. Режим доступу: http: // www.nbuv.gov.ua.

2. Підгірна В. С. Нормативно-правове забезпечення формування та використання прибутку суб'єктів господарювання / В. С. Підгірна // Актуальні проблеми соціально-економічного розвитку Європейських країни : матеріали міжнародної науково-практичної конференції, Черкаси, 31 жовтня 2014 року. - Черкаси, 2014. - С. 49-51.

3. Офіційний сайт Державної служби статистики України [Електронний ресурс]. - Режим доступу: http://www.ukrstat.gov.ua/.

4. Білошапка В. А. Резерви зростання результативності бізнесу в умовах економічного спаду / В. А. Білошапка // Актуальні проблеми економіки. - 2011. - №1(155). - C. 115. 
Вісник Львівського торговельно-економічного університету. Економічні науки. № 62, 2021

\section{REFERENCES}

1. Basiurkina, N. J. Analiz i otsinka zovnishnikh i vnutrishnikh chynnykiv formuvannia prybutku u vynorobnij haluzi, Ekonomika kharchovoi promyslovosti, available at: http: // www.nbuv.gov.ua.

2. Pidhirna, V. S. (2014), Normatyvno-pravove zabezpechennia formuvannia ta vykorystannia prybutku sub'iektiv hospodariuvannia, Aktual'ni problemy sotsial'no-ekonomichnoho rozvytku Yevropejs'kykh krainy : materialy mizhnarodnoi naukovo-praktychnoi konferentsii, Cherkasy, 31 zhovtnia 2014 roku, s. 49-51.

3. Ofitsijnyj sajt Derzhavnoi sluzhby statystyky Ukrainy, available at: http://www.ukrstat.gov.ua/.

4. Biloshapka, V. A. (2011), Rezervy zrostannia rezul'tatyvnosti biznesu $\mathrm{v}$ umovakh ekonomichnoho spadu, Aktual'ni problemy ekonomiky, №1(155), s. 115.

Стаття надійшла до редакиії 24 листопада $2020 p$. 